Nowoczesne Systemy Zarządzania

Zeszyt 12 (2017), nr 4 (październik-grudzień)

ISSN 1896-9380, s. 119-129

Modern Management Systems

Volume 12 (2017), No. 4 (October-December)

ISSN 1896-9380, pp. 119-129
Instytut Organizacji i Zarządzania

Wydział Cybernetyki

Wojskowa Akademia Techniczna

w Warszawie

Institute of Organization and Management

Faculty of Cybernetics

Military University of Technology

\title{
Rola przywództwa we współczesnych Siłach Zbrojnych RP
}

\section{The role of leadership in the contemporary Polish armed forces}

\author{
Piotr Chrobot \\ Doktorant Szkoły Głównej Handlowej w Warszawie
}

\begin{abstract}
Abstrakt. Bardzo wielu przywódców zapisało się w historii świata wielkimi literami, w zebranym materiale postarałem się opisać ich cechy osobowościowe, jak również style kierowania, dzięki którym oddziaływali na innych, by osiągać założone cele. Ponadto celem artykułu jest ukazanie roli współczesnego przywódcy w Siłach Zbrojnych RP.

Słowa kluczowe: przywództwo, kierowanie zespołami ludzkimi, lider, przywódca, cechy osobowościowe przywódcy, style zarządzania.
\end{abstract}

Abstract: Many leaders have written in the history of the world in large letters, in the collected material I tried to describe their personality traits as well as styles of leadership, through which they influenced others to achieve their goals. In addition, the aim of the article is to show the role of a modern leader in the Armed Forces of the Republic of Poland.

Key words: leading, leadership, team management, leader, personality traits of the leader, management styles.

„Kto chce rządzić ludźmi, nie powinien ich gnać przed sobą, lecz sprawić, żeby podążali za nim"

Montesquieu

Celem referatu jest refleksja teoretyczna i metodologiczna nad kwestią przywództwa we współczesnych Siłach Zbrojnych RP. Nie ulega wątpliwości, że jesteśmy świadkami „przyspieszonych” zmian zachodzących w Wojsku Polskim. Wymiana kadry kierowniczej jest konsekwencją wygranych wyborów parlamentarnych w 2015 r. 
przez partię Prawo i Sprawiedliwość. Nowy minister obrony narodowej, co zrozumiałe, obsadza kluczowe stanowiska osobami, które darzy zaufaniem. Kwestię tę dostrzega znakomity socjolog prof. Piotr Sztopmka w książce pt. Zaufanie - fundament społeczeństwa, wskazując, że aby aktywnie i konstruktywnie zmierzyć się z przyszłością, należy okazywać zaufanie, co czynią właśnie politycy wyznaczani do kierowania instytucjami zhierarchizowanymi, jakimi jest m.in. Wojsko Polskie. Dobierając w odpowiedni sposób osoby funkcyjne, minister obrony narodowej wierzy, że przyjęta przez niego strategia jest przez nie aprobowana oraz dzięki nim osiągnie założone cele (Sztompka, Kraków 2007, s. 45). O strategii tego typu, gdzie na pierwsze miejsce, jako umiejętność strategiczna, wysuwany jest człowiek, pisze prof. Maria Romanowska w książce pt. Planowanie strategiczne w przedsiębiorstwie, dostrzega jego kompetencje i motywacje do podejmowania dobrych decyzji. Osoba kompetentna, zmotywowana podejmuje dobre decyzje zarządzające. Autorka nazywa takie działanie „poszukiwaniem kamienia filozoficznego" (Romanowska, Warszawa 2004, 2009, s. 16).

Obecnie, zgodnie z przyjętymi założeniami, co wielokrotnie podkreśla w swoich wystąpieniach minister obrony narodowej, stawia się najczęściej na ludzi młodych, rozpoczynających swoją karierę zawodową w latach 90 . Czy słusznie? Osoby z tych roczników dorastały przecież po przemianach ustrojowo-gospodarczych i były pierwszym pokoleniem rozpoczynającym życie zawodowe w kapitalizmie, a PRL pamiętają tylko $\mathrm{z}$ lat młodości. $\mathrm{W}$ ten właśnie sposób dokonuje się zmiana pokoleniowa w strukturach Wojska Polskiego. Należy zadać sobie pytanie, gdzie w tym wszystkim należy dopatrywać się przywództwa. Czy nowo powołani dowódcy, szefowie, dyrektorzy czy też kierownicy wyznaczeni rozkazem personalnym bądź decyzją są w stanie „pociągnąć za sobą” swoich podwładnych? Aby odpowiedzieć na to pytanie, zdefiniujmy samo pojęcia przywództwa.

Przywództwo to oddziaływanie na zachowania innych. Jest to rodzaj społecznego wpływu, który pojawia się, gdy jedna osoba, w tym przypadku przywódca, jest zdolna do powodowania pożądanego przez siebie zachowania u innej osoby. Następuje to z powodu więzi, jaka ich łączy, czy też powodu społecznego stosunku, jaki między nimi zachodzi. Przywództwo to sztuka mobilizowania ludzi do skutecznych działań. Jego istotą jest wywieranie szczególnego wpływu w obrębie grupy po to, by zbliżyć ją do celu, jakim jest trwałe zaspokajanie jej istotnych potrzeb.

Natomiast przywódca to ktoś, kto kieruje działaniami innych i rozwija je, starając się zapewnić stałe doskonalenie. Słowo przywódca wywodzi się z języka angielskiego - leading, leadership - przewodzić. Reasumując, można przyjąć, że przywódca zna wytyczoną drogę, idzie nią i ukazuje podążającym za nim. Można go nazwać również przewodnikiem, wizjonerem, motywatorem czy też mentorem. Osobę przewodzącą można bez większego trudu wyłonić spośród grupy ludzi, wystarczy obserwować, czyja opinia jest najcenniejsza podczas kolejnego wypracowywania decyzji, komu poświęca się więcej uwagi podczas dyskusji, kto uzyskuje szybko zgodę i poparcie ogółu, czy też za kim podąża grupa. 
Urodzeni przywódcy należą do rzadkości, ale byłbym skłonny przyjąć tezę, że przywództwa można się nauczyć. Co zatem sprawia, że wybrańcy stają się przywódcami i źródłem inspiracji dla innych? Specjalista od zagadnień związanych z psychologią sukcesu Brian Tracy w książce pt. Przywództwo - odkryj w sobie potencjat przywódcy ukazuje kolejno etapy drogi osoby z predyspozycjami zarządzającymi, by stać się przywódcą. Należą do nich:

- pozyskiwanie zaufania ludzi i cieszenie się ich lojalnością;

- budzenie poczucia celu w organizacji;

- myślenie strategiczne i posiadanie ogólnego obrazu sytuacji;

- przekształcanie trudności w okazje do wykorzystania;

- podejmowanie właściwego ryzyka;

- jasne mówienie o celach i strategiach oraz zdobywanie poparcia dla nich;

- tworzenie zwycięskich zespołów;

- pomaganie zwykłym ludziom w osiąganiu nadzwyczajnych wyników;

- pielęgnowanie wartościowych relacji i wykorzystywanie prawa wzajemności;

- stawanie się naturalnym kandydatem na przywódcę, który poprowadzi organizację do zwycięstwa (Tracy, Warszawa 2015).

Przywódca to lider, szczególny rodzaj kierownika, dowódcy, który bezpośrednio wpływa na zachowania członków swojego zespołu, podwładnych. Mając na nich duży wpływ, powoduje, że wykonują oni polecenia pożądane przez szefa. Dzieje się tak ze względu na szczególny rodzaj więzi, jakie ich łączą. Podwładni skłonni są zaufać swojemu przywódcy i podporządkować mu się dobrowolnie. Można również powiedzieć, że taka osoba cieszy się autorytetem, a jej zwierzchnictwo jest dla większości grupy akceptowalne, co nie jest często spotykane we współczesnym świecie.

Ciekawą definicję przywództwa nakreślił prof. Stanisław Mika, twierdząc, że przywództwo postrzegane jest jako pewna zdolność, umiejętność lub cecha zjednywania sobie zwolenników, wywierania wpływu, a także tworzenia wizji rozwoju i pobudzania ludzi do działania (Mika, Warszawa 1987).

Zatem jaki tak naprawdę powinien być przywódca? Jakie cechy osobowościowe powinien posiadać? Czym się wyróżniać? Jak zauważa w swoim artykule Marcin Balzer, cechą charakterystyczną lidera jest to, że ludzie chcą go naśladować oraz łatwo poddają się jego przywództwu, oczekują od swych przywódców pomocy w wykonaniu wspólnego zadania, wypracowania zasad współdziałania w zespole oraz reakcji na poszczególnych członków grupy i zaspokojenia ich potrzeb. Według autora lider to osoba, która posiada autorytet, jest wpływowa i z tego tytułu pełni określone funkcje społeczne. Do cech pożądanych zalicza się:

- wizjonerstwo,

- zaangażowanie,

- pewność siebie,

- zdecydowanie,

- szybkość w działaniu, 
- uczciwość,

- serdeczność,

- autentyczność,

- twardość, ale sprawiedliwość,

- umiejętności organizacyjne.

Nie można myśleć o przywództwie bez dawania osobistego przykładu. Może on przybierać różne formy, ale musi mieć miejsce. Przywódca powinien dawać przykład, a nie stawiać siebie za przykład. Najlepiej odbieranym dobrym przykładem jest ten nieświadomy, wynikający $\mathrm{z}$ tego, kim się tak naprawdę jest, $\mathrm{w}$ przeciwieństwie do zachowania zmierzającego do wywołania skrupulatnie obliczonego efektu, tzw. „bycia na pokaz". Jeśli dawanie przykładu stanie się nawykiem, lider nie będzie o tym myślał, stanie się to naturalne. Niepożądanym efektem jest natomiast chlubienie się przed samym sobą, że jest się tak dobrym liderem. Jak dalej zauważa autor, jeśli lider ma skutecznie przewodzić innym w takiej samej mierze przez przykład osobisty, jak i innymi środkami, musi posiąść jeszcze jedną cechę: skromność, a nawet pokorę. Jest to najrzadziej spotykana cecha przywódcy, którą odznaczają się wyłącznie najlepsi (Balzer, www.artelis.pl, 2012).

Przywódcy to ludzie, którzy potrafią oddziaływać na innych bez potrzeby uciekania się do użycia siły, ponadto osoby te są akceptowane przez innych w tej roli. Przywództwo polega m.in. na tworzeniu wizji i pobudzaniu swoich podwładnych, członków zespołu, wykorzystując zwiększenie ich motywacji do realizacji założonego celu. Skuteczni przywódcy odznaczają się pożądanymi cechami lub właściwościami. Lider-przywódca nie tylko kieruje działaniami innych ludzi, lecz także pracuje $\mathrm{z}$ nimi dla osiągnięcia wspólnych celów, pomaga ludziom je precyzować, wytycza zadania, współuczestniczy w analizie i rozwiązywaniu grupowych i indywidualnych problemów.

Liderzy muszą sprawić, by ich wizja stała się wspólną wizją. Gdy myślimy o nich, mamy na myśli np. ich charyzmę, umiejętność przewidywania, przekonywania, zaangażowania $\mathrm{w}$ to, co robią.

Cechy będące wyznacznikami przywództwa można w sobie wykształcić. Przywództwa nie można w sobie odkryć - trzeba je rozwijać. Nieliczni „urodzeni przywódcy”, jak to się mówi potocznie, „wypłyną”, lecz aby utrzymać swój status, muszą rozwijać i doskonalić wrodzone predyspozycje. Ludzie garną się do przywódców skoncentrowanych na przyszłości. To oni, odnosząc sukcesy w przewodzeniu, zdają sobie sprawę, że rozwijanie tych umiejętności jest zajęciem na całe życie, ich zdobywanie jest procesem, który nigdy się nie kończy. Przywódcze uzdolnienia i umiejętności kierowania ludźmi są ważnym czynnikiem ich skuteczności.

John W. Gardner sformułował pięć wskaźników pozwalających odróżnić przywódców od zwykłych kierowników (menedżerów). Oto one:

- przywódca myśli długofalowo, wybiegając daleko poza problemy bieżące;

- przywódca posiada szczególne umiejętności radzenia sobie ze sprzecznymi potrzebami zespołu; 
- przywódca przywiązuje wagę do wizji, wartości i motywacji;

- przywódca nie akceptuje aktualnego stanu rzeczy, poszukuje lepszych, efektywniejszych rozwiązań;

- przywódca nie ogranicza się w swych zainteresowaniach do zakresu zadań, stara się nieustannie je poszerzać i zwiększać również zakres swych wpływów (Gardner, Leading Minds: An Anathomy of Leadership, Basic Books, New York, 1995).

Jeśli ktoś pojawia się w grupie jako przywódca, jest to wynik posiadania przez niego pewnych potrzebnych cech. W pracy zbiorowej pod redakcją D.M. Stewart przedstawiono cechy uznawane za najcenniejsze na najwyższym szczeblu zarządzania w kolejności ich znaczenia i tam przywództwo znalazło się na drugim miejscu, tuż za umiejętnością podejmowania decyzji. Następnie zostały wymienione takie cechy jak: prawość, entuzjazm, wyobraźnia, chęć ciężkiej pracy, umiejętności analityczne, zrozumienie dla innych, umiejętność dostrzegania okazji, umiejętność sprostania nieprzyjemnym sytuacjom, zdolność szybkiego przystosowania się do zmian, skłonność do podejmowania ryzyka, umiejętność jasnego wypowiadania myśli, przedsiębiorczość, bystrość umysłu, umiejętność sprawnego administrowania, otwartość umysłu, wytrwałość czy też zdolność do pracy przez wiele godzin. Wyróżniki te ustalono na podstawie ankiety przeprowadzonej wśród skutecznie działających dyrektorów naczelnych dobrze prosperujących przedsiębiorstw, co pokazuje, jak ważną cechą jest przywództwo w grupie (Stewart, Warszawa 1996, s. 26).

Z kolei Daniel Goleman wymienia charakterystyczne cechy wybitnego lidera:

- samoświadomość emocjonalna,

- emocjonalna samokontrola,

- ukierunkowanie na osiąganie celów,

- pozytywny światopogląd (optymizm),

- zdolność adaptacji,

- empatia,

- świadomość organizacyjna,

- rola nauczyciela i mentora,

- zarządzanie konfliktami,

- charyzma,

- praca zespołowa.

Przywódca kreuje rzeczywistość, wykorzystując do tego trzy podstawowe style kierowania: autokratyczny, demokratyczny oraz liberalny. Krótko postaram się omówić każdy z nich.

W stylu autokratycznym przełożony sam określa cele grupowe i zadania do wykonania, arbitralnie (nie dopuszczając sprzeciwu) decyduje o podziale pracy, wydaje rozkazy i polecenia, stanowcze oceny zarówno negatywne, jak i rzadziej pozytywne, stosuje raczej kary niż nagrody. Konsekwencją stosowania tej metody może być osiągnięcie wysokiej efektywności, jakość i oryginalność jest raczej niska, 
słaba motywacja. Wewnątrz grupy może dochodzić do zachowań agresywnych, apatii czy uległości i podporządkowania. $Z$ całą pewnością nie możemy tu mówić o zadowoleniu podwładnych z pracy, a raczej o występowaniu u nich frustracji.

Inaczej jest $\mathrm{w}$ stylu demokratycznym, gdzie przełożony sam zachęca do podejmowania decyzji, przedstawiania swoich pomysłów. Stawia się tu na pracę grupową, daje prawo udziału w podejmowaniu decyzji oraz nie ingeruje w realizację zadań. Wynikiem działań będzie wysoka jakość pracy, efektywność mniejsza niż w stylu autokratycznym i duża motywacja do pracy. Jeśli chodzi natomiast o stosunki wewnątrz grupy, to pojawiają się pożądane zjawiska - jak wzrost integracji w grupie, życzliwość, a nawet przyjaźń. Wszystkie te pozytywne aspekty przekładają się na duże zadowolenie z pracy jej uczestników.

W ostatnim stylu, liberalnym, przełożony pozostawia większą swobodę, nie ingeruje w pracę podwładnych, nie komentuje, nie ocenia - udziela natomiast wskazówek na ich prośbę. Odbija się to jednak negatywnie na efektywności pracy oraz jej bardzo niskich wynikach. Wynikiem takiego stylu jest powstawanie nieformalnych struktur, pojawia się brak zaufania i dezintegracja oraz mamy do czynienia z wymuszaniem posłuszeństwa. Nie można też mówić w tym przypadku o zadowoleniu z pracy (Sakowska, www.trecko.pl, Goleman, 2013).

Inne spojrzenie na style kierowania przedstawił dr Ken Blanchard, współautor bestsellerów Jednominutowy menedżer oraz Cała naprzód!. Wyróżnia on cztery podstawowe style przywództwa:

- dyrektywny - gdzie przywódca przekazuje konkretne wskazówki i ściśle nadzoruje wykonanie zadania;

- trenerski - przywódca nadal kieruje wykonaniem zadania i je nadzoruje, lecz wyjaśnia też decyzje oraz prosi o sugestie i wspiera;

- $\quad$ wspierający - przywódca ułatwia podwładnym wykonanie zadania i wspiera ich, dzieli się odpowiedzialnością za podejmowanie decyzji;

- delegujący - przywódca przekazuje podwładnym odpowiedzialność za podejmowanie decyzji i rozwiązywanie problemów (Blanchard, Zigarmi, Zigarmi, Warszawa 2008, s. 30).

Specjalistka z zakresu psychologii behawioralnej dr S. Weinschenk w książce pt. Motywacja i perswazja. Jak sprawić, by inni robili to, co chcesz ciekawie opisała siedem rodzajów bodźców motywujących, dzięki którym jesteśmy w stanie osiągnąć zamierzony cel:

- potrzeba więzi,

- nawyki,

- sugestywność opowieści o sobie samym,

- kij i marchewka,

- instynkty,

- pragnienie dojrzałości,

- złudzenia poznawcze (Weinschenk, Warszawa 2014, s. 13). 
Ważną kwestią są również role funkcjonujące w każdej zbiorowości. Doskonale pogrupował je Zbigniew Zaborowski, dzieląc na:

I. Role zadaniowe - zachowania, które przybliżają grupę do osiągnięcia założonego celu:

- inicjator - często proponuje nowe rozwiązania, wychodzi z nowymi pomysłami,

- kontynuator - przechwytuje pomysły inicjatora, rozwija i kontynuuje, zajmuje się zadaniami już rozpoczętymi,

- poszukujący informacji - zadaje dużo pytań, stara się ustalić istotne dla grupy zadania i fakty,

- dostarczający informacji - przekazuje grupie posiadane informacje, obserwacje etc.,

- koordynator - pilnuje, aby każdy miał odpowiednią liczbę zadań do wykonania, dzieli pracę między poszczególnych członków zespołu,

- nawigator - przypomina o celu, informuje, na jakim etapie projektu znajduje się obecnie grupa,

- oceniający - ocenia postępy poszczególnych członków grupy oraz całości, podsumowuje, wyciąga na tej podstawie wnioski.

II. Role społeczne - ważne dla współżycia i rozwoju grupy:

- zachęcający - motywuje, namawia do aktywności, zachęca, wspiera osoby, które z różnych powodów źle się czują,

- harmonizator - dba, aby wszyscy w równy sposób uczestniczyli w życiu grupy, pilnuje równomiernego podziału obowiązków i zasobów, pomaga w konfliktach, dąży do kompromisów,

- rozładowujący napięcia - trudne sytuacje przedstawia w jasnych barwach, często zamienia w żart, proponuje rozrywkowe, rozładowujące działania,

- strażnik zasad - pilnuje, aby wszyscy trzymali się zasad i norm, przypomina o nich innym członkom grupy.

III. Role utrudniające współżycie i współpracę w grupie:

- blokujący - przeciwstawia się pomysłom i inicjatywom grupowym, podważa zasadność tego, co się dzieje, często kieruje się celami osobistymi,

- poszukujący uznania - niezależnie od tego, co się dzieje w grupie i co jest ważne, zwraca na siebie uwagę - podkreśla swoje zasługi (często bezpodstawnie), demonstruje swoje zdolności i możliwości,

- dominujący - nie dopuszcza innych do głosu, zachowuje czołową pozycje w zespole, narzuca swoje zdanie, manipuluje innymi,

- unikający - nie podejmuje inicjatyw grupowych, unika włączania się w zadania grupy, stara się być na uboczu, nie podejmuje ryzyka,

- plotkarz - rozprasza grupę przez rozmowy z sąsiadującą osobą, zwykle nie na temat, może tworzyć podgrupy, liczni gadatliwi członkowie grupy zwykle siadają koło niego, nie jest w stanie trzymać tematu dyskusji, 
- playboy - podkreśla i obnosi się ze swoim brakiem zaangażowania $\mathrm{w}$ procesy grupowe, a jego postępowanie może przybierać formę cynizmu, nonszalancji, niewybrednych żartów itp.,

- poszukujący pomocy (sierotka) - usiłuje wywołać współczucie innych, wyrażając nadmierną niepewność, lęk, zagubienie, deprecjonując własną wartość.

Podsumowując, każdy zespół, przynajmniej jednokrotnie, przechodzi przez proces grupowy, który składa się z czterech głównych faz i kończy dojrzałością grupy. W każdej fazie przed przywódcą stoją bardzo ważne zadania, to on bowiem koordynuje pracę i działanie całego zespołu, wyznaczając cel i misję. W miarę rozwoju grupy jego nadzorująca rola traci na znaczeniu, staje się bardziej inicjatorem zmian, koordynatorem, partnerem. Ważne jest również, by potrafił identyfikować role przyjmowane przez poszczególnych członków zespołu i w odpowiedni sposób na nie reagować (wzmacniać pozytywne i przekształcać negatywne w pozytywne) (Zaborowski, Warszawa 1997).

Przyjrzyjmy się zatem przywództwu w odniesieniu do instytucji zhierarchizowanej, jaką jest wojsko. Począwszy od najmniejszego zespołu, czyli drużyny, sekcji, poprzez związki taktyczne jak brygada czy dywizja, a skończywszy na szczeblu operacyjnym oraz strategicznym. Na czele każdego z nich stoi wyznaczony decyzją czy rozkazem przełożonego dowódca. Zespół taki, przynajmniej w założeniu, jest zgrany, współpracując, dąży do osiągnięcia celów założonych przez tegoż dowódcę. Dowódca postawiony na czele zespołu ludzi powinien zdawać sobie sprawę z tego, że dobry i efektywny zespół nie powstaje z dnia na dzień i należy nad nim pracować. Powinien również wiedzieć, że w grupie takiej zachodzą procesy grupowe, występuje różnego rodzaju aktywność poszczególnych członków, funkcjonują i kształtują się role społeczne, wypracowywane zostają sposoby działania, normy i zasady dotyczące członków. Pomiędzy tymi osobami dochodzi do określonych interakcji, tj. współpracy, rywalizacji bądź konfliktów.

Jakie zatem kwalifikacje dowódczo-przywódcze, rozumiane jako zdolność do kierowania zespołami ludzkimi, powinien mieć dowódca stojący na czele takiej organizacji? Bo przecież „Dowodzenie jest sztuką, która jest domeną i kunsztem dowódcy..." (Cz. Jarecki, M. Sołoducha, Dowodzenie artyleria, SGWP, Warszawa 2000, s. 24). Źródłem podporządkowania się woli dowódcy jest jego autorytet osobisty, wyrażający się w uznaniu przełożonego za przywódcę formalnego. Autorytetem jest tutaj prestiż osoby oparty na uznanych i cenionych w danym środowisku wartościach. Nie ulega wątpliwości, że osoba taka powinna nieustannie pracować nad doskonaleniem swych umiejętności przywódczych. Istnieją różne metody, przy pomocy których w wojsku należy kształtować oraz wzmacniać kompetencje dowódcze, tj.:

- samokształcenie,

- udział w treningach i ćwiczeniach,

- uczestnictwo w kursach i szkoleniach, 
- umiejętność słuchania podwładnych i przełożonych,

- umiejętność wyciągania wniosków nie tylko z porażek, ale i z sukcesów.

Niebagatelną rolę odgrywają również kompetencje społeczne dowódcy takie jak:

- wiedza,

- umiejętności (m.in. umiejętność życia wśród ludzi i współpracy z nimi),

- doświadczenie,

- postawa.

Szczególnie ważne w środowisku wojskowym wydają się być takie kompetencje przywódcze jak:

- wywieranie wpływu na innych,

- zdolność przekonywania,

- motywowanie,

- umiejętność skutecznego komunikowania się,

- umiejętność rozwiązywania konfliktów,

- umiejętność kontrolowania emocji,

- duża odporność na stres.

Zadania dowódcy i jego kompetencje w zarządzaniu i kierowaniu powierzoną grupą są szczególnie istotne w osiąganiu założonych celów, np. bojowych postawionych przez jego przełożonych czy też wynikających z potrzeby chwili, szczególnie istotnych w działaniach na linii frontu. Doskonale zdawali sobie z tego sprawę wielcy przywódcy tacy jak: Hannibal, Aleksander Wielki, Napoleon, Fryderyk Wielki, George Patton, Dwight Eisenhower czy George Washington. Żaden z nich nie urodził się przywódcą, tylko się tego nauczył. Zatem wszystko w rękach i głowach dowódców różnego szczebla, którym minister obrony narodowej powierzył tę jakże odpowiedzialną misję.

Doskonałym narzędziem wyrabiania w sobie cech przywódczych jest czytanie biografii najwybitniejszych przywódców. Abraham Lincoln napisał: „To, iż niektórzy ludzie odnieśli sukces, świadczy o tym, że inni też mogą". Potwierdził to również wielki filozof Bertrand Russell, pisząc „Najlepszym dowodem na to, że coś można zrobić, jest fakt, że inni ludzie już to zrobili’. Szczególnie ciekawy dla mnie jest przykład Aleksandra Wielkiego, który tego, jak być wielkim, uczył się od ósmego roku życia, a efektem jego ciężkiej pracy nad sobą jest przykład bitwy pod Arbelą (bitwa pod Gaugamelą), gdzie poprowadził 50-tysięczną armię do frontalnego ataku na milionową armię perską, którą rozgromił. Aleksander, podobnie jak wszyscy wybitni przywódcy, potrafił organizować ludzi i inspirować ich do ponadprzeciętnych osiągnięć. Jego życie i historia jego podbojów są znakomitym przykładem połączenia wszystkich wielkich cech przywódczych (Tracy, Warszawa 2015, s. 10-11).

A jakiego, drogi Czytelniku, Ty masz szefa, dowódcę? Z kim na co dzień współpracujesz? Mamy przecież wysokie oczekiwania wobec przywódców. Mówimy, że powinien on być taki lub inny, narzekamy, że „mój szef jest najgorszym szefem, jakiego miałem podczas swojej służby, bo...” lub „ktoś, kto kieruje powinien znać się na tym i na tamtym, czy nie powinien robić tego czy tamtego". Dzieje się tak, 
gdyż nasze opinie na temat liderów kształtują się na podstawie doświadczeń i spostrzeżeń. Nie ma idealnych dowódców, przywódców, tak samo jak nie ma idealnych podwładnych. Uważam, że każdy ambitny, wykształcony, doświadczony dowódca ciągle pracuje nad metodami oddziaływania na podwładnych, by stały się celowe, skuteczne i efektywne, mobilizowały do pozytywnych i pożądanych założonych działań. Udowodniono, że przeciętny człowiek wykorzystuje w pracy mniej niż 50 procent swoich możliwości, a czasem tylko 40 procent. Przywódcy potrafią wydobyć $z$ ludzi dodatkowe 30,40 , a nawet 50 procent możliwości i sprawić, aby osiągali wyniki znacznie lepsze niż kiedykolwiek wcześniej (Tracy, Warszawa 2015, s. 30).

$\mathrm{Na}$ co dzień spotykamy w siłach zbrojnych różnych dowódców, są tacy, którzy chcą służyć tylko sobie, nie Ojczyźnie. Można ich zdemaskować na dwa sposoby. Po pierwsze, obserwować, jak reagują na informacje o sobie. Osoby takie nienawidzą informacji niepochlebnych o sobie. Po drugie, przejawiają niechęć do rozwijania się innych liderów w ich otoczeniu, czują się zagrożeni (Blanchard, Warszawa 2016, s. 43). Dlatego też nie dbają o rozwój osobisty podwładnych, nie kierują ich na kursy, szkolenia czy studia, gdyż nie chcą wypaść na ich tle słabiej. Są również tacy, którzy nie potrafią pochwalić podwładnego za jego dotychczasowe osiągnięcia, a jego choćby najmniejsze potknięcie wykorzystują do „publicznej chłosty”. Tego typu zarządzanie nazywamy mewim. Dowódcy wlatują, robią dużo hałasu, obrzucają wszystkich łajnem, a potem wylatują (Blanchard, P. Zigarmi, D. Zigarmi, Warszawa 2008, s. 38). Niestety z tym stylem, „ignoruj i eliminuj”, wciąż mamy do czynienia. W szczególności stosowany jest przez ludzi mających już bardzo bogate doświadczenie, na całe szczęście zarówno dla wojska, jak i samych żołnierzy dowódców tych z każdym dniem jest coraz mniej i z całą pewnością nie można ich nazwać przywódcami. Armia staje się nowoczesna, dobrze zarządzana przez ludzi młodych, otwartych, doskonale przygotowanych do pełnienia coraz bardziej odpowiedzialnych zadań. Jestem przekonany, że doświadczenia zebrane przez oficerów w misjach poza granicami Rzeczypospolitej zaowocują pojawieniem się na kierowniczych stanowiskach w Wojsku Polskim przywódców na miarę czasów, w jakich przyszło nam żyć.

Zdajemy sobie sprawę, że jako członek NATO musimy niejako wpisywać się $\mathrm{w}$ trend zachodniej polityki kadrowej naszych partnerów, gdzie wiedza, doświadczenie, ale i otwartość na nowe rozwiązania są szczególnie cenione. We współczesnych Polskich Siłach Zbrojnych stawia się na profesjonalizm, oddanie, a sprawne i umiejętne dowodzenie jest konieczną, ale niewystarczającą przesłanką zwycięstwa. Nieumiejętne, niesprawne dowodzenie może być wystarczającym powodem klęski. Swój wywód o przywództwie w dzisiejszych Siłach Zbrojnych zakończę stwierdzeniem, że pod dowództwem dobrego generała nie ma złych żołnierzy!

„Szlachetny człowiek wymaga od siebie, prostak od innych”

Konfucjusz

Qiu (丘) 


\section{LITERATURA}

[1] BALzer M., 2012, Jak skutecznie zarządzać zespołem i stać się charyzmatycznym przywódcą, www.artelis.pl.

[2] Blanchard K., 2016, Przywództwo wyższego szczebla, Warszawa.

[3] Blanchard K., Zigarmi P., Zigarmi D., 2008, Jednominutowy menedżer i przywództwo, Warszawa.

[4] Gardner H., 1995, Leading Minds: An Anatomy of Leadership, Basic Books, New York.

[5] JARecki CZ., SoŁoducha M., 2000, Dowodzenie artylerią, SGWP, Warszawa.

[6] Mika S., 1987, Psychologia społeczna, Warszawa.

[7] Romanowska M., 2004, 2009, Planowanie strategiczne w przedsiębiorstwie, Warszawa.

[8] Sakowska P., 2013, Mistrzowie zarządzania - Daniel Goleman, artykuł, www.trecko.pl.

[9] Stewart D.M. (red.), 1996, Praktyka kierowania, PWE, Warszawa.

[10] Sztompka P., 2007, Zaufanie - fundament społeczeństwa, Kraków.

[11] Tracy B., 2015, Przywództwo - odkryj w sobie potencjał przywódcy, Warszawa.

[12] Weinschenk S., 2014, Motywacja i perswazja. Jak sprawić, by inni robili to, co chcesz, Warszawa.

[13] ZавоRоwsкi Z., 1997, Trening interpersonalny, Warszawa. 
